\title{
$\mathrm{Py}-\mathrm{GC} / \mathrm{MS}$ 분석법을 이용한 첨가물 혼합 옻칠 접착제의 정성분석
}

\section{Study on Qualitative Analysis for Lacquer Mixed with Some Additives by Pyrolysis-Gas Chromatography/Mass Spectrometry}

\author{
Ji Eun Kim | Ji A Yu | Yong Jae Chung' \\ Department of Heritage Conservation \& Restoration, Graduate School of Convergence Cultural Heritage, \\ Korea National University of Cultural Heritage, Buyeo, 33115, Korea \\ ${ }^{1}$ Corresponding Author: iamchung@nuch.ac.kr, +82-41-830-7365
}

\begin{abstract}
초 록 옻칠은 천연도료로써 기원전 1 2세기부터 한반도에서 사용되었으며 접착제로도 활용되었다. 이러한 접착제로 써의 기능은 고문헌과 실제 출토되는 유물에서 찾을 수 있으며, 아교, 밀가루, 어교 등을 혼합하여 사용했다는 사실을 확인할 수 있다. 본 연구는 첨가물을 혼합한 칠의 정성분석을 통하여 칠분석 및 혼합재료에 대한 분석가능성을 확인해보 고자 하였다. 첨가물을 혼합한 칠에 대한 정성분석 결과, EGA분석을 통해 옻, 찹쌀풀, 아교의 열분해 온도를 확인하였다. 이를 바탕으로 Py-GC/MS 분석을 통해 생칠 시료의 경우 우루시올 곁사슬(R기)에서 유래된 열분해 산물을 확인하였으 며, 찹쌀풀과 아교 각각 글루코오스와 아미노산에서 유래된 물질로 추정되는 성분이 검출되었다. 본 연구를 통해 옻과 첨가물별 최적의 열분해 온도를 확인하였으며, 열분해 산물에 대한 기초 정성분석 값을 제시하였다. 첨가물 혼합 비율별 정성분석을 실시하여 실제 유물에서 관찰되는 칠 접착제 분석 가능성을 확인하였다.
\end{abstract}

중심어: 옻칠, 찹쌀풀, 아교, 열분해 가스크로마토그래피, $E G A$

\begin{abstract}
Lacquer has been used as a natural paint or adhesive in Korea since 2nd century B.C. It has been found to have been used as an adhesive as mentioned in old records and as seen in excavated relics, It was also mixed with flour, animal glue, or fish glue to produce lacquer adhesives. Qualitative analysis and evaluation of the applicability of lacquer and additives was performed in this study. The results of EGA analysis for lacquer additives confirmed that the pyrolysis temperature of lacquer, glucose glue, and animal glue. On the basis of this result, raw lacquer sample was checked that pyrolysis product that originated from urushiol side chain (R group). Components originating from glucose and amino acid were detected in glutinous rice paste and animal glue samples. In this study, the optimum pyrolysis temperature for each lacquer and additive mixture was determined from basic qualitative analysis data. By performing the qualitative analysis of each mixture, the applicability of this technique for analyzing real relics was evaluated.
\end{abstract}

Key Words: Lacquer, Glucose glue, Animal glue, Pyrolysis gas chromatography, EGA 


\section{1. 서 론}

옻칠은 예로부터 한국과 중국, 일본에서 금속이나 목공 도장용으로 가장 소중히 여겨왔던 도료로써 기원전 1 2세 기부터 한반도에서 도료로 사용되었다. 우리나라는 기원 전 3 세기 충청남도 아산 남성리 석관묘에서 옻칠의 흔적을 확인하였으며, 이를 통해 중국과 다른 독자적인 칠문화가 존재하였음을 알 수 있다(Choi et al., 2011). 특히 고려시 대에는 나전칠기가 고급 공예품으로 성행하면서 칠기의 가치가 높았다. 현재는 다양한 기법을 응용하여 칠기 외에 회화, 도자 등 칠을 활용한 예술품이 제작되고 있다. 칠은 목공 도장용 등의 도료로써 사용되었으며 국보 제 32 호 합 천 해인사 대장경판은 그 예로 판목을 옻칠하여 사용하였 다(Do and Lee, 1999). 최근에는 친환경 소재로써 각광받 으며 각종 건물의 도장도료로 활용하기 위한 연구가 진행 되고 있는 추세이다(Kim and Lee, 2002).

생칠은 도막을 만들기 위해 사용한 천연도료뿐만 아니 라 접착제의 기능을 가지고 있다. 가례도감의궤에서는 칠 기를 제작하는데 필요한 재료로 아교, 부레, 매칠, 풀가루 등을 언급하여 칠기 제작과정에 옻 외에 다양한 천연접착 제가 사용된다는 사실을 확인할 수 있다(Park, 2013). 또한 칠기 제작 과정에서 나전칠기 하지층에 백골과 삼베 접착 을 위하여 칠과 찹쌀풀을 혼합한 호칠이 사용된다. 호칠은 통상적으로 부피비 5:5로 혼합하여 사용하며, 상당한 접착 력이 있다고 알려져 있다.

실제 칠기를 제작하는 장인들도 건조속도를 높이기 위 해 첨가물을 혼합하였으며, 특히 항아리 등을 수리하는데 사용하였다고 언급하였다. 과거 일본에서 도자기 수리 시 생칠과 아교를 혼합하여 사용하였으며, 첨가물 혼합 시 첨 가제가 많을수록 옻의 질과 특성이 저하되기 때문에 옻의 비율을 높게 혼합하여 사용하였다.

국내 고문헌에서 무기질 재료를 접착·복원하는데 혼합 물로써 옻칠에 아교와 밀, 백반 등을 사용한 것을 확인할 수 있다. 조선시대 과학기술서인 『오주서종박물고변(五洲 書種博物考辨)』에서는 깨진 자기를 붙이는 방법으로 생옻 에 달걀 흰자위와 백반가루를 섞어서 붙이면 매우 단단하 며, 좋은 옻에 가는 체로 친 밀가루를 조금 섞어 붙인다고 언급하였다(Yang, 2014). 가정살림에 관한 내용의 책인 『규합총서(閏閤叢書)』에서는 벼룻돌, 질그릇을 붙이는 방 법으로 체에 친 고운 밀가루와 생옻을 혼합한다고 언급하 였다(Yang, 2014). 고문헌을 통해 예로부터 칠에 첨가물을 혼합하여 사용한 사실을 확인할 수 있으며 첨가물은 단백
질계, 셀룰로오스계 등을 사용하여 현재까지 사용하는 재 료와 유사하다는 사실을 알 수 있다.

또한 옻칠을 접착제로 사용한 사례는 출토되는 유물에 서도 확인할 수 있다. 평택 대추리 유적 출토 원삼국시대 대형옹은 수리 흔적이 남아있었으며, 접합부위에서 관찰 되는 접착재료에 대하여 푸리에 변환 적외선 분광분석, 열 분해 기체 크로마토그래피/질량분석 결과 옻칠 성분임을 확인하였다(Cho et al., 2010). 또한 일본 시모야케베 지역 에서 출토된 죠몬토기 접합부위에 사용된 접착재료에 대 한 분석결과 칠이라는 결과가 나왔다(Jang, 2015). 현재 문 화재 수리 현장에서도 옻칠을 접착제로 종종 사용하며, 성 혈사 나한전 창호 보수시 문살 결합에 아교와 옻을 혼합하 여 사용하였다고 한다(Jang, 2015).

옻칠 및 접착재료에 대한 분석으로는 과거 출토 칠기 등 을 대상으로 현미경, 전자현미경, 적외선분광분석, 열분해 기체크로마토그래피/질량분석 등을 통한 칠 기법 및 도막 의 특성 규명연구가 진행되었다(Kim, 2007). 최근에는 옻 칠의 전처리 없이 정성분석이 가능한 열분해 기체크로마 토그래피/질량분석이 칠 분석에 적극적으로 활용되고 있다. 국외에서는 열분해 기체크로마토그래피/질량분석을 통해 칠기유물에서 채취한 시료를 대상으로 아시아, 유럽 등 산 지별 칠의 성분을 확인하였으며(Lu et al., 2012), 수산화테 트라메틸암모늄(Tetra methyl ammonium hydroxide; TMAH) 전처리 방법으로 유럽산 옻칠의 화학성분을 분석한 연구 도 진행되었다(Saverwyns et al., 2014). 또한 국내에서도 열분해 기체크로마토그래피/질량분석을 이용하여 옻칠과 황칠의 화학적 조성을 비교분석하기 위한 연구가 수행되 었다(Shin and Ahn, 2013). 그러나 기존의 연구는 유물 외 부의 칠도막에 대한 분석에 그쳤으며 복합적인 재료로 제 작되는 칠기 즉, 첨가물이 혼합된 칠에 대한 정성분석 연구 는 미비한 실정이다. 따라서 본 연구는 최근 칠 분석에 유 용하게 사용되는 열분해 $\mathrm{GC} / \mathrm{MS}$ 를 이용하여 첨가제가 혼 합된 칠 접착제에 대한 열분해 양상과 열분해 주요 산물에 대한 정성분석을 실시하여 향후 칠 유물 분석을 위한 기초 자료를 제시하고자 한다.

\section{2. 연구 대상 및 방법}

\section{1. 시료제작}

옻은 중국산 생칠을 사용하였다. 옻에 혼합한 천연접착 제의 종류는 단백질계, 셀룰로오스계에 대하여 각각 찹쌀 풀과 아교를 사용하였다. 찹쌀풀의 경우 현대 옻칠공예에 
서 옻과 혼합하여 호칠이라는 명칭으로 하지층 작업에 접 착제 역할로 사용되며 아교의 경우 예로부터 공예에서 가 장 흔하게 사용하는 재료로 단백질계 첨가물로 사용하였다. 찹쌀풀은 국내산 찹쌀가루(100\%)와 물을 부피비 1:2.5로 혼합 후 고온에 15 분 이상 저어서 제조하였다. 아교는 일본 봉황사(社)에서 제조한 막대아교와 물을 부피비 1:4로 혼 합 후 물 온도 $55^{\circ} \mathrm{C}$ 에서 중탕하였다. 찹쌀풀과 아교는 칠 과 혼합 시 뭉침을 형성하기 위하여 고농도로 사용하였다.

열분해 기체 크로마토그래피/질량분석을 위한 시료는 칠과 첨가물을 부피비 5:5로 혼합하여 유리판(Slide glass, $75 \times 25 \mathrm{~mm})$ 에 일정량 $(0.2 \mathrm{~g})$ 도포하여 상온 $\left(\right.$ 온도 $18 \pm 2^{\circ} \mathrm{C}$, 습도 $55 \pm 10 \%$ )에서 건조하였다.

\section{2. 정성분석}

\subsection{1. $\mathrm{EGA}$ 분석}

첨가물이 혼합된 칠 접착제의 열분해 최적온도를 확인 하기 위하여 EGA(Evolved Gas Analysis)법을 이용하였 다. EGA방법은 시료를 빠른 시간 안에 열분해하여 생성된 가스를 분석한다. 승온 조건에 따라 온도별 휘발성분을 실 시간으로 검출하여 시료의 열적특성을 파악할 수 있다. 특 히 고분자 분석 시 첨가물이 존재할 경우 첨가물과 고분자 는 명백하게 분해온도가 다르기 때문에 구성물질의 열분 해 온도를 구할 때 유용하게 사용된다.

열분해 장비는 PY-3030D(Frontier Lab, Japan)를 사용 하였으며 소프트웨어 F-Search를 사용하여 승온 구간에 따른 열분해 양상을 확인하였다. 열분해는 $50^{\circ} \mathrm{C}$ 에서 1 분 유지 후 분당 $10^{\circ} \mathrm{C}$ 씩 $800^{\circ} \mathrm{C}$ 까지 승온시켰다(Table 1$)$.

2.2.2. 열분해 기체 크로마토그래피 분석

열분해 기체 크로마토그래피/질량분석법(Pyrolysis Gas
Chromatography/Mass Analysis; Py-GC/MS)을 이용하여 칠에 혼합된 첨가물 접착제의 열분해 산물을 확인하고자 하였다. Py-GC/MS는 고분자 물질에 순간적으로 높은 온 도를 가하여 시료를 순식간에 분해하여 분석할 수 있게 하 는 유용한 방법이다. 분석하고자 하는 시료가 쉽게 휘발되 어야 한다는 특성을 보완한 방법으로 휘발성이 없는 천연 고분자 분석에 자주 사용되는 추세이다. 특히 소량의 시료 만으로도 쉽게 분석할 수 있으며, 특별한 전처리가 필요 없 어 문화재 분석에서도 다양하게 활용된다. Py-GC/MS의 분석 방법으로 싱글샷(Single shot)은 한 가지 고온조건에 서 열분해를 시켜 열분해 산물의 성분 분석 값을 얻는 방법 을 말하며, 더블샷(Double shot)은 시료에 열을 점차적으 로 가하여 특정 범위에서 시료를 기화시키는 방법을 말한 다. 더블샷은 고분자 분석 시 첨가물이 존재할 경우 첨가물 과 고분자의 열분해 온도를 구분하여 분석할 수 있어 유용 하게 사용된다.

열분해 장비는 PY-3030D(Frontier Lab, Japan)를 사용 하였으며 GC는 Agilent사의 7890A, MS는 5975MSD를 사용하였다. EGA를 통해 칠, 찹쌀풀, 아교의 최적 열분해 온도 확인 후 결과를 바탕으로 각 시료를 열분해하여 GC 에서 기화된 기체를 분리하여 질량 분석하였다. 주입구의 온도는 $250^{\circ} \mathrm{C}$ 로 $50: 1$ 의 기체를 주입하였다. 컬럼은 Agilent 사의 DB-5MS (5\%-Phynyl-methyl polysiloxane, $30 \mathrm{~m} \times$ $250 \mu \mathrm{m} \times 0.25 \mu \mathrm{m})$ 를 사용하였으며, 헬륨(99.999\%)을 분 당 $1 \mathrm{ml}$ 주입시켰다. 오븐은 초기온도 $55^{\circ} \mathrm{C}$ 에서 1 분간 유 지 후 $280^{\circ} \mathrm{C}$ 까지 분당 $10^{\circ} \mathrm{C}$ 씩 승온하였다. 질량분석기는 $70 \mathrm{eV}$ 에서 이온화 시켜 50 800 분자범위에서 분석하였으 며, Chemstation(Willey 7Nist08)을 이용하여 정성분석을 실시하였다(Table 2). 첨가물 혼합 시료의 경우 특성 이온 만을 선택하여 검출하는 SIM(Selectd Ion Monitoring)모 드를 사용하여 분석하였다.

Table 1. The condition of EGA

\begin{tabular}{ccc}
\hline \multirow{2}{*}{ Py } & Temp. programing & $\begin{array}{c}\text { Initial } 50^{\circ} \mathrm{C}(1 \mathrm{~min}), \text { Rate } 10^{\circ} \mathrm{C} / \mathrm{min} \\
\left.\text { Final } 800{ }^{\circ} \mathrm{C} \text { (Total } 77 \mathrm{~min}\right)\end{array}$ \\
\cline { 2 - 3 } & Column & EGA capillary tube (Length=2.5 m, id:0.15 mm) \\
\cline { 2 - 3 } GC & Carrier gas $(99.999 \%)$ at $1 \mathrm{ml} / \mathrm{min}$ \\
\cline { 2 - 3 } & Injection port temp. & $250^{\circ} \mathrm{C}$ \\
\cline { 2 - 3 } & Injection mode & Split (50:1) \\
\cline { 2 - 3 } & Oven temp. programing: & $300^{\circ} \mathrm{C}(77$ min) \\
\hline Data acquisition & F-Search (Frontier Lab.) \\
\hline
\end{tabular}


Table 2. The condition of pyrolysis GC/MS

\begin{tabular}{|c|c|c|c|}
\hline & \multirow{3}{*}{ Pyrolysis temp. } & Lacquer & $500^{\circ} \mathrm{C}$ \\
\hline & & Glucose glue/ Additives & $330^{\circ} \mathrm{C}$ \\
\hline & & Animal glue / Additives & $345^{\circ} \mathrm{C}$ \\
\hline \multirow{7}{*}{$\begin{array}{l}\mathrm{G} \\
\mathrm{C}\end{array}$} & Column & DB-5MS (5\%-Phynyl-m & $\mathrm{e}, 30 \mathrm{~m} \times 250 \mu \mathrm{m} \times 0.25 \mu \mathrm{m})$ \\
\hline & Carrier gas & $\mathrm{He}(99.999 \%)$ at $0.5 \mathrm{ml} / \mathrm{m}$ & \\
\hline & \multirow{3}{*}{ Injection port temp. } & Lacquer & $300^{\circ} \mathrm{C}$ \\
\hline & & Glucose glue/ Additives & $250^{\circ} \mathrm{C}$ \\
\hline & & Animal glue / Additives & $300^{\circ} \mathrm{C}$ \\
\hline & Injection mode & Split (50:1) & \\
\hline & Oven temp. programing: & Initial $50^{\circ} \mathrm{C}$, Rate $10^{\circ} \mathrm{C} / \mathrm{m}$ & $10 \mathrm{~min})$ \\
\hline \multirow{6}{*}{$\begin{array}{c}\mathrm{M} \\
\mathrm{S}\end{array}$} & Transfer temp. & $300^{\circ} \mathrm{C}$ & \\
\hline & Ionization mode & Electron impact (EI) & \\
\hline & Electron energy & $70 \mathrm{eV}$ & \\
\hline & Ion source temp. & $230^{\circ} \mathrm{C}$ & \\
\hline & Mass range & $\mathrm{m} / \mathrm{z} 50 \sim 800$ & \\
\hline & Data acquisition & ChemStation (Wiley7Nis & \\
\hline
\end{tabular}

Table 3. Pyrolysis temperature for samples

\begin{tabular}{cccccc}
\hline & Lacquer & Glucose glue & Animal glue & $\begin{array}{c}\text { Glucose glue } \\
\text { additive }\end{array}$ & $\begin{array}{c}\text { Animal glue } \\
\text { additive }\end{array}$ \\
\hline $\begin{array}{c}\text { Initial } \\
\text { temp. }\left({ }^{\circ} \mathrm{C}\right)\end{array}$ & 300 & 280 & 280 & 320 & 280 \\
\hline $\begin{array}{c}\text { Optimum } \\
\text { temp. }\left({ }^{\circ} \mathrm{C}\right)\end{array}$ & 455 & 330 & 345 & 445 & 445 \\
\hline $\begin{array}{r}\text { Ended } \\
\text { temp. }\left({ }^{\circ} \mathrm{C}\right)\end{array}$ & 480 & 380 & 510 & 500 & 500 \\
\hline
\end{tabular}

\section{3. 결과 및 고찰}

\subsection{EGA 분석}

$\mathrm{EGA}$ 분석결과, 옻은 $300^{\circ} \mathrm{C}$ 에서 열분해가 일어나기 시 작하면서 $455^{\circ} \mathrm{C}$ 에서 최대의 열분해가 일어나는 것을 확인 하였다. 찹쌀풀은 $280^{\circ} \mathrm{C}$ 에서 열분해가 일어나며 $330^{\circ} \mathrm{C}$ 에 서 최고로 열분해 되는 것을 확인하였다. 아교는 $280^{\circ} \mathrm{C}$ 에 서 시작하여 $345^{\circ} \mathrm{C}$ 에서 최대의 열분해가 일어났다(Table 3). 칠과 첨가물이 혼합된 시료의 경우, 찹쌀풀 혼합 시료
는 $320^{\circ} \mathrm{C}$ 에서 열분해가 시작되어 $445^{\circ} \mathrm{C}$ 에서 최대의 분해 가 일어나며, 아교 혼합시료는 $280^{\circ} \mathrm{C}$ 에서 열분해가 시작 되어 $445^{\circ} \mathrm{C}$ 에서 최대의 분해가 일어나는 것을 확인하였다 (Table 3).

칠은 $455^{\circ} \mathrm{C}$ 에서 최대의 열분해가 일어나는 것을 확인 하였다. 이는 생칠이 $4300^{\circ} \mathrm{C}$ 에서 열분해가 발생한다고 보 고한 연구사례와 유사한 패턴을 보였다(Lu et al., 2012). 찹쌀풀은 $3300^{\circ} \mathrm{C}$ 에서 최대의 열분해가 진행되었는데, 이와 같은 결과는 전분은 전반적으로 $250^{\circ} \mathrm{C}$ 부근에서 분해되기 시작하여 $360^{\circ} \mathrm{C}$ 정도에서 분해가 완료되었다고 보고된 바 
와 유사하였다(Kim et al., 1989). 최대 열분해 온도에서 관 찰되는 온도 차이는 전분의 기원으로 인한 것으로 추정된 다. 아교는 $345^{\circ} \mathrm{C}$ 에서 최대의 열분해가 일어났다. 칠과 첨 가물이 혼합된 시료의 경우 찹쌀풀 혼합 시료, 아교 혼합 시료 모두 $445^{\circ} \mathrm{C}$ 에서 최대의 열분해가 일어났는데, 이는 칠의 최대 열분해 구간과 동일하며, 칠과 혼합 시 첨가물의 열분해 온도는 확인되지 않는 것으로 판단된다.

\section{2. 열분해 기체 크로마토그래피 분석}

단일물질 열분해 산물에 대한 정성분석결과, 옻칠의 열 분해 산물은 머무름 시간(Retention Time; RT) 3 10분에 벤젠계열의 성분인 Toluen(1), Ethyl Benzene(2), Penthyl
Benzene(3)이 분석 되며, 11분 이후부터 1-Tetradecene(4), 1,13-Tetradecadiene(5), 8-Heptadecene(6) 등의 긴 탄소사 슬이 검출되었다(Figure 1 ).

생칠의 주성분으로 검출된 1,13-Tetradecadiene(Figure 2), 8-Heptadecene(Figure 3)은 칠의 구성성분으로 알켄류 인 8-Heptadecene, 1-Heptadecene와 알칸류 Tetradecane 가 분석된 값과 유사한 결과로 나타났다(Shin and Ahan, 2013). 본 연구에서 분석된 성분은 우루시올의 알킬기(R 기)에서 기인한 물질로 추정되는데, 우루시올은 벤젠고리 환에 2개의 수산기가 결합되어 있으며, 탄소수 15 18개로 구성된 알킬기로 구성되어있다. 옻의 특성은 우루시올 알 킬기의 탄소수와 이중결합의 수에 의해 결정된다. 칠의 열 분해 유도체인 8-Heptadecene과 1,13-Tetradecadiene은

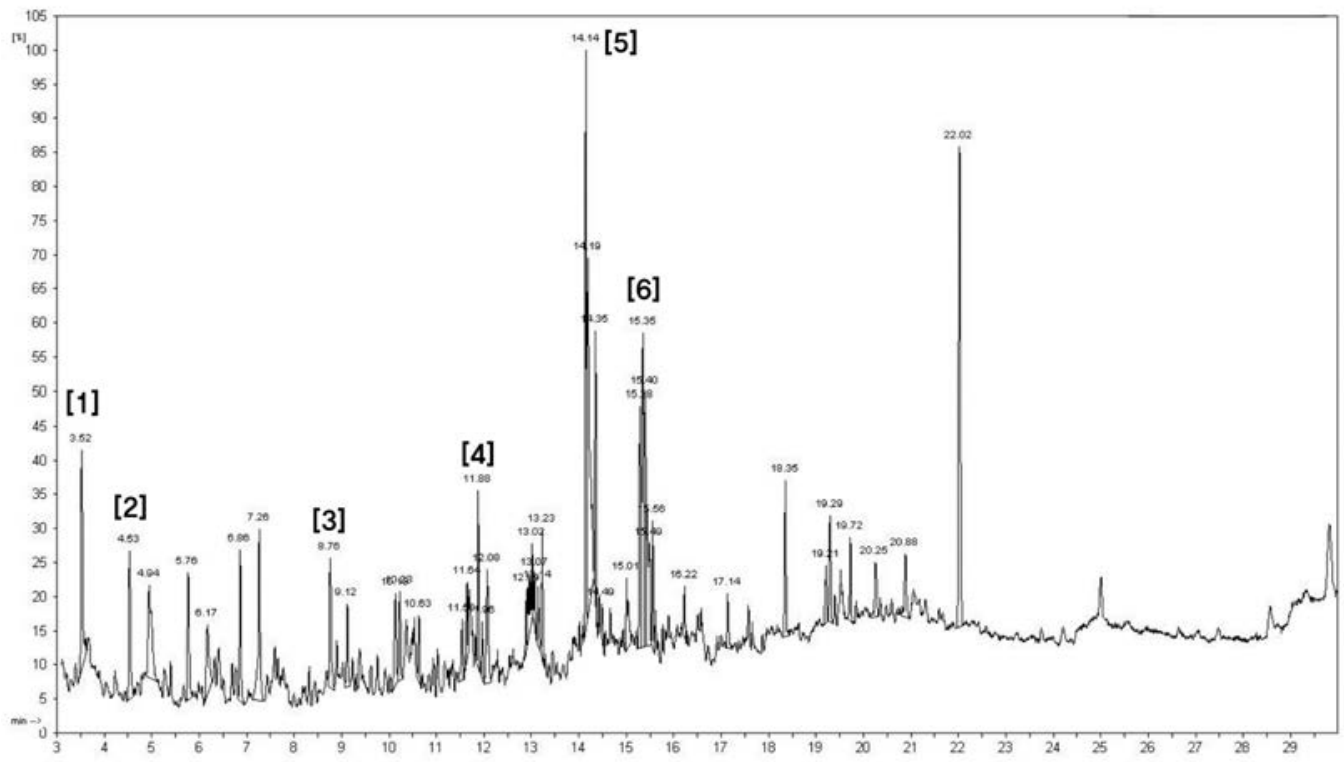

Figure 1. Total ion chromatogram of lacquer(1:Toluen, 2:Ethyl Benzene, 3: Penthyl Benzene, 4:1-Tetradecene(4), 5:1,13-Tetradecadiene, 6:8-Heptadecene).

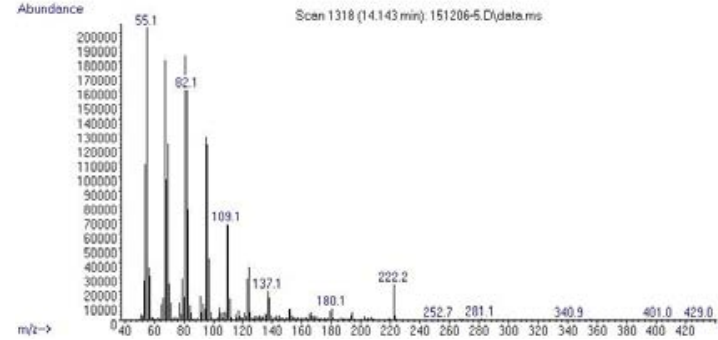

Figure 2. Mass spectra of 1,13-Tetradecadiene.

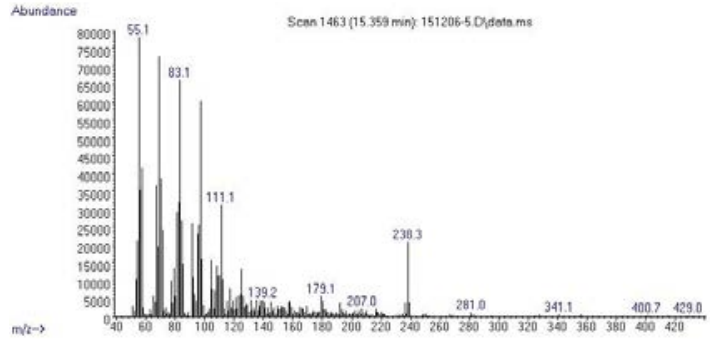

Figure 3. Mass spectra of 8-Heptadecene. 
우루시올 알킬기에서 유래된 물질로 이중결합 부위에서 분해되어 나타난 산물로 추정된다. 이는 고분자 열분해 시 일반적으로 이중결합 부위에서 분해되는 확률이 높기 때 문이다(Lu et al., 2012). 이를 통해 중국산 생칠의 우루시 올 알킬기의 탄소수와 이중결합구조를 유추할 수 있었다.
찹쌀풀의 열분해 산물은 5-(Hydroxymethyl)-2-Furaldehyde (1), Levoglucosan(3), D-Glucono-SLactone(5) 등이 분석 되었다(Figure 4). 찹쌀풀 열분해 주요산물로 5-(Hydroxymethyl)2-Furaldehyde, Levoglucosan, D-Glucono-SLactone 등이 검출되었으며 이는 전분의 기본구조인 글루코오스에서 기

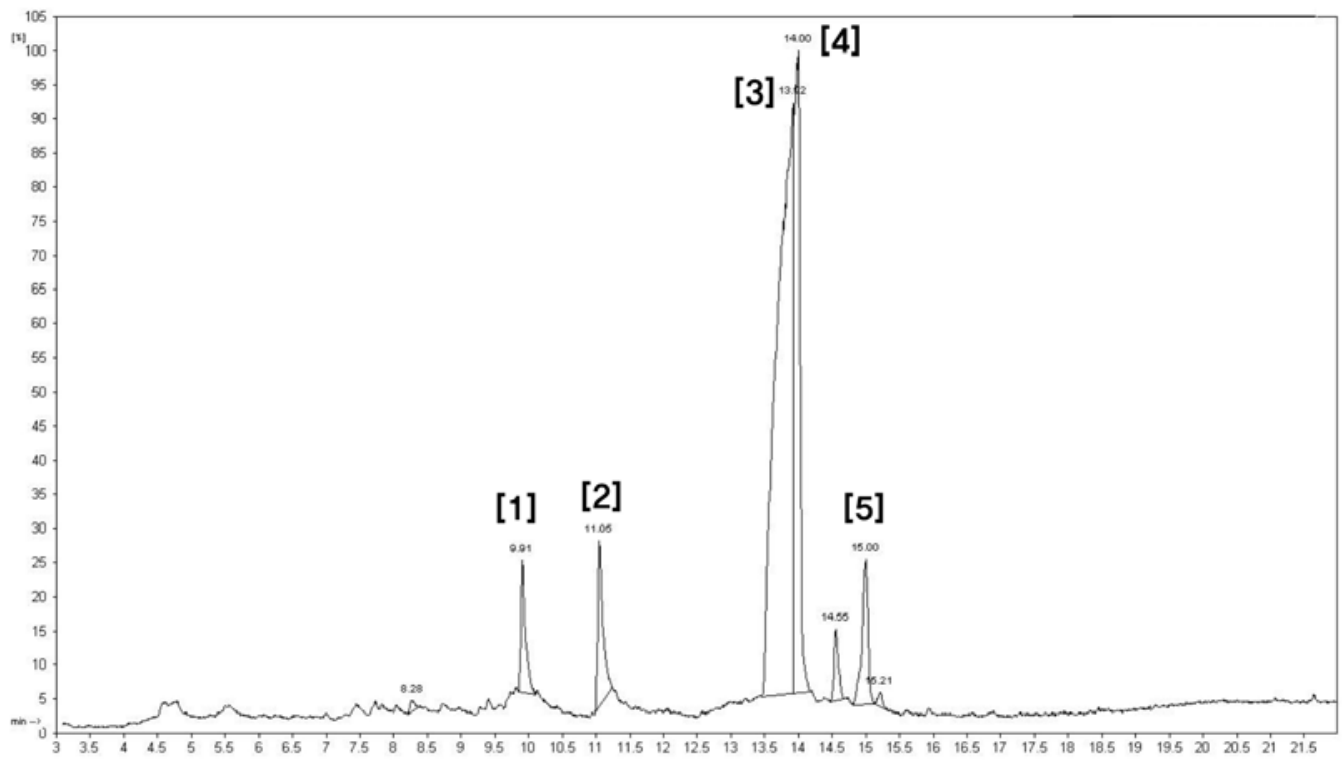

Figure 4. Total ion chromatogram of glucose glue(1:5-(Hydroxymethyl)-2-Furaldehyde, 2:1,1-Dimethyl2-Propyl-Hydrazine, 3:D-Allose, 4:Levoglucosan, 5:D-Glucono- $\delta$-Lactone).

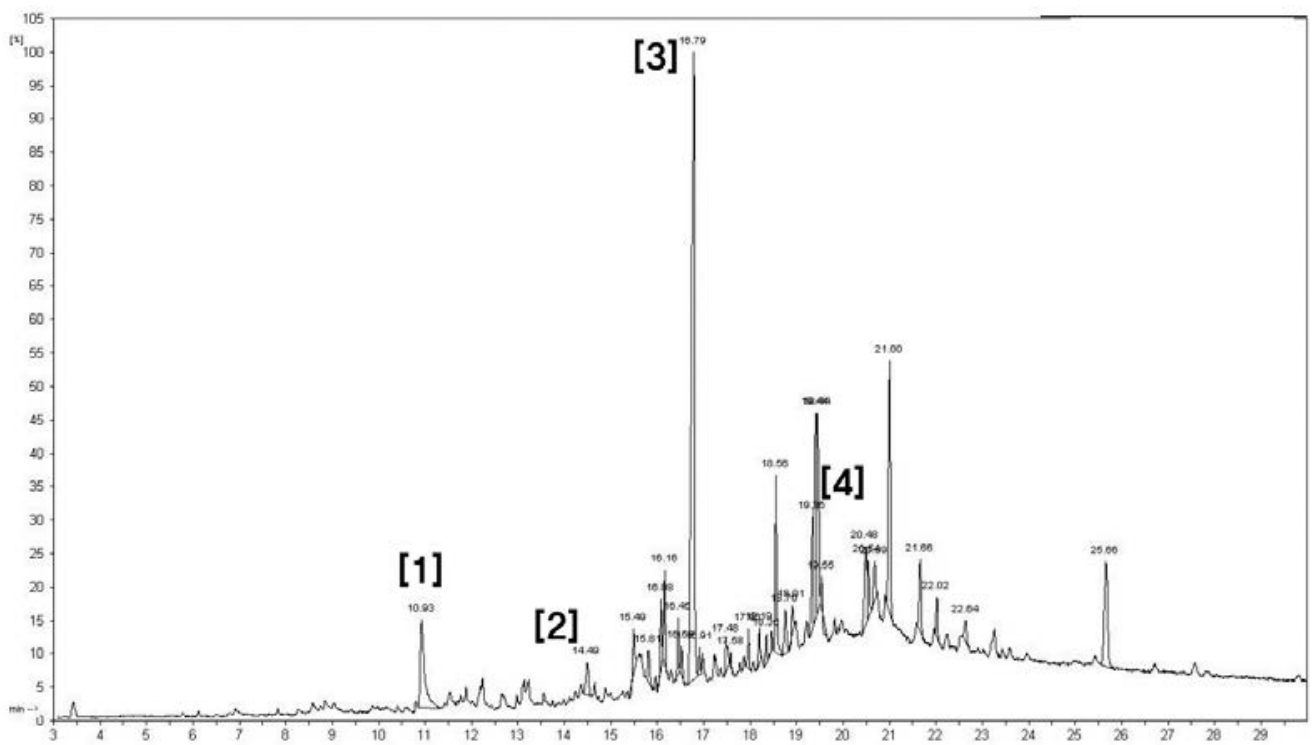

Figure 5. Total ion chromatogram of animal glue(1:Pyrrole-2-Carboxamide, 2:5-Isopropenyl-2-Methylcyclohexanol, 3:Hexahydro-Pyrrolo[1,2-a]Pyrazine-1,4-Dione, 4:1H-Indole). 
인한 물질로 추정된다. 전분의 열분해 및 분석에 관한 연구 에서 전분을 $358^{\circ} \mathrm{C}$ 로 열분해 시켰을 때 검출된 2-Furaldehyde, 2-Hydroxy-Methyl Furan와 동일계열의 물질로 판단된다 (Kim et al., 1989). Furan계 화합물은 당류들이 열분해하 여 형성하는 물질이며, Levoglucosan의 경우 유도체화를 거치지 않은 탄수화물에서 공통적으로 생성되는 열분해 산물로 글루코오스의 탈수반응으로 인해 물분자가 하나 떨어진 구조이다(Kim, 2009).

아교의 열분해 산물은 Pyrrole-2-Carboxamide(1), Hexahydro-
Pyrrolo[1,2-a]Pyrazine-1,4-Dione(3), 1H-Indole(4) 등 Phenol 계열분해산물을 확인할 수 있었다(Figure 5). Pyrrole-2Carboxamide, Hexahydro-Pyrrolo[1,2-a]Pyrazine-1,4-Dione 등은 단백질 구조의 한 종류인 하이드로프롤린에서 유래 된 것으로 추정된다. 하이드로프롤린은 콜라겐에 $12.8 \%$, 젤라틴에 $7.4 \%$ 포함되어있으며, 케라틴, 피브로인, 카제인 등의 단백질에는 포함되어있지 않다. 이러한 성질로 하이 드로프롤린은 접착제와 고착재료로 사용되는 아교분석의 지표가 되는 성분이다. 특히 Pyrrole은 하이드로프롤린의

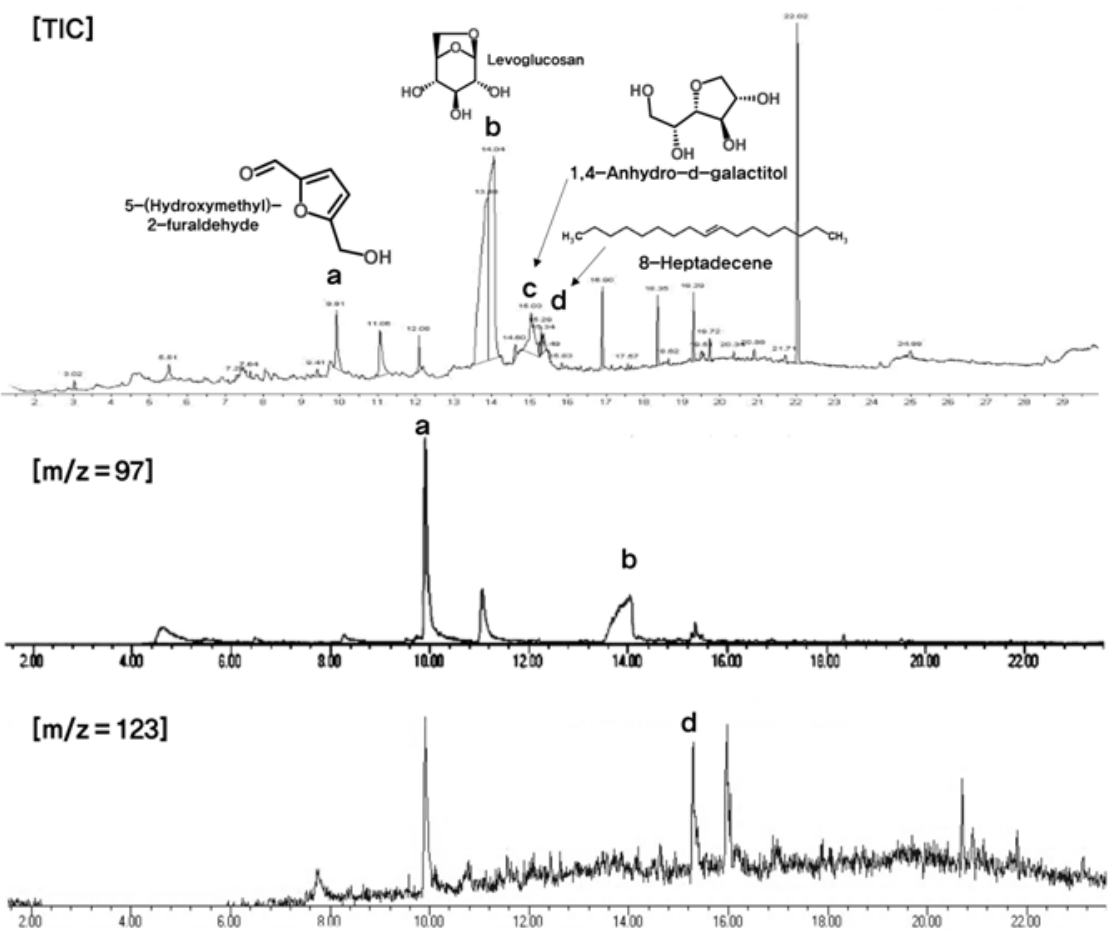

Figure 6. Pyrolysis data of glucose glue additives(a:5-(Hydroxymethyl)-2-Furaldehyde, b:Levoglucosan, c:1,4Anhydro-d-galactitol, d: 8-Heptadecene).
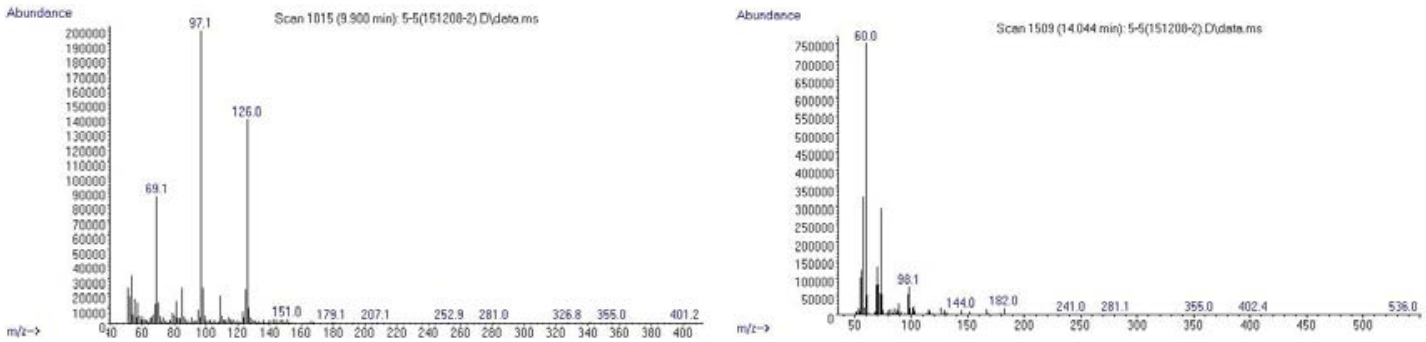

Figure 7. Mass spectra of 5-(Hydroxymethyl)-2- Figure 8. Mass spectra of Levoglucosan. Furaldehyde. 
열분해 산물로 알려져 있다(Shedrinsky and Baer, 2006). 본 연구에서도 이와 동일한 열분해 산물을 확인하였으며, 단백질의 아미노기 $\left(-\mathrm{NH}_{2}\right)$ 에 유래된 열분해 산물로 추정할 수 있었다.

첨가물 혼합 시료에 대한 열분해 산물 정성분석결과, 찹쌀풀 혼합시료의 경우 RT 9.91, 14.04에서 각각 5-(Hydroxymethyl)2-Furaldehyde(Figure 7), Levoglucosan(Figure 8), 15.03 에서 1,4-Anhydro-d-Galactitol 등 찹쌀풀의 열분해 산물 과 동일 성분이 검출되었으며, RT 15.35 에서 생칠의 열분 해 산물인 8-Heptadecene가 검출되었다(Figure 6). 질량스
펙트럼 m/z 97에서 찹쌀풀 유래성분 5-(Hydroxymethyl)2-Furaldehyde, Levoglucosan이 확인되었으며, 알켄계열 의 질량스펙트럼에 해당하는 $\mathrm{m} / \mathrm{z} 123$ 에서 옻칠 유래성분 1,13-Tetradecadiene과 8-Heptadecene을 확인할 수 있었 다(Figure 6).

아교 혼합시료 분석 결과, 9.14에서 N-MethylmorpholineN-Oxide(Figure 10), 16.72에서 Hexahydro-Pyrrolo[1,2-a] Pyrazine-1,4-dione(Figure 11) 등 아교에서 유래된 산물이 검출되었다(Figure 9). 또한 15.29, 15.35, 15.49에서 각각 1,13-Tetradecadiene, 8-Heptadecene등 옻의 열분해 산물과
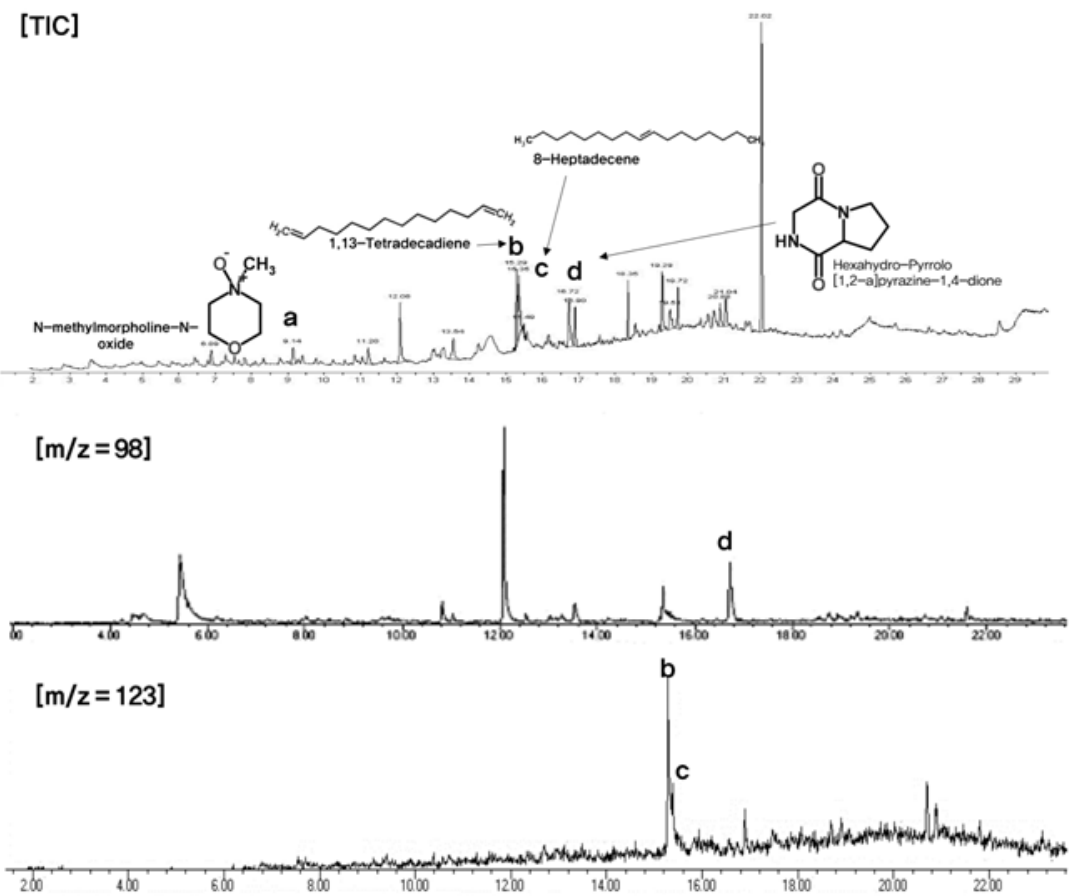

Figure 9. Pyrolysis data of Animal glue Additives(a:N-Methylmorpholine-N-Oxide, b:1,13-Tetradecadiene, c:8-Heptadecene d:Hexahydro-Pyrrolo[1,2-a]Pyrazine-1,4-dione).

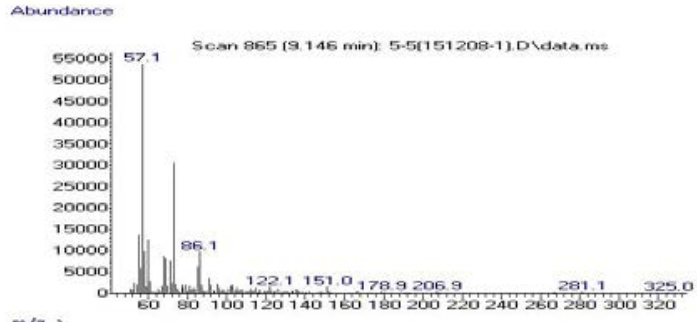

Figure 10. Mass spectra of N-Methylmorpholine-N-Oxide

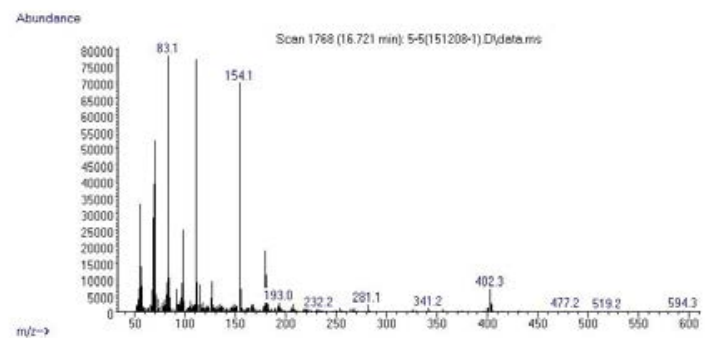

Figure 11. Mass spectra of Hexahydro-Pyrrolo[1,2-a] Pyrazine-1,4-dione. 
동일한 성분이 검출되었다(Figure 9). 아교혼합시료는 m/z 98에서 아교유래성분 Hexahydro-Pyrrolo[1,2-a]pyrazine1,4-dione가 검출되었으며, $\mathrm{m} / \mathrm{z} 123$ 에서 옻칠 유래성분 1,13-Tetradecadiene과 8-Heptadecene이 확인되었다(Figure 9).

\section{4. 결 론}

본 연구는 Py-GC/MS를 통해 첨가제가 혼합된 칠 접착 제의 열분해 양상 및 산물을 제시하였다. 칠의 열분해 산물 은 우루시올 이중결합에서 분해된 알킬기가 검출되었으며, 찹쌀풀과 아교 각각 글루코오스, 아미노산에서 기원한 열 분해 물질을 확인하였다. 이처럼 각 재료의 특성에 따라 검 출되는 열분해 화합물의 특징적 차이는 칠 접착제 정성분 석에 유용할 것으로 사료된다.

특히 복합물질의 경우 컬럼을 통해 나온 이온화될 수 있 는 모든 것을 단순히 검출한 전체이온크로마토그램(TIC) 에서 한 개의 질량에 대한 이온전류를 선택적으로 측정하 는 방법(SIM Mode)이 유용하게 활용된다. 칠에 혼합된 첨 가물을 분석하는 경우, 칠에 소량 혼합된 첨가물에 대하여 선택적으로 열분해 산물을 확인할 수 있었다.

추후 첨가물 혼합 비율에 따른 정성분석연구가 필요할 것으로 사료되며, 실제 유물에서 관찰되는 칠 접착제 분석 에 적용가능성을 확인할 수 있었다.

\section{REFERENCES}

Cho, N.C., Kim, S.C., Kim, W.H. and Shin, Y.S., 2010, A study on the bonding materials used for the great jar of the proto-three kingdoms period from Daechuri site, Pyeongtaek. Journal of Conservation Science, 26(4), 371-376. (in Korean with English abstract)

Choi, J.C., Kim, S.D., Lee, Y.H., Go, S.R. and Ham, S.U., 2011, Studies on analysis of Joseon lacqeur layer. Journal of Conservation Science, 27(4), 371-380. (in Korean with English abstract)

Do, C.H. and Lee, T.N., 1999, Lacquer coatings on the Koryo buddhist canon printing wood blocks. Journal of Conservation Science, 11(8), 33-39. (in Korean)

Jang, S.Y., 2015, A study of characteristics and modern application for lacquer. International Symposium Presentation
File of The Color of Baekje, Buyeo, October 2, 90-99. (in Korean)

Kim, H.J. and Lee, B.H., 2002, Development trends of natural coatings-rhus lacquer, dendropanax lacquer and cashew nutshell liquid(CLSL) lacquer-. Journal of Applied Chemistry for Engineering, 4(5), 35-43. (in Korean)

Kim, M.C., 2009, Pyrolysis behaviors of carbohydrate using pyrolysis-GC and pyrolysis-GC/MS. Master's thesis, Sejong University, Seoul. (in Korean with English abstract) Kim, P.Z., Hong, S.M. and Kim, C.H., 1989, Studies on therma degradation and analysis of starches by pyrolysisgas chromatography/mass spectrometry. Journal of Korean Society of Analytical Science, 2(1), 115-123. (in Korean with English abstract)

Kim, S.C., 2007, Analysis and conservation of lacquer wares from archaeological sites in Korea. Ph. D. dissertation, Chungbuk National University, Cheongju. (in Korean with English abstract)

Lu, R., Honda, T. and Miyakoshi, T., 2012, Application of pyrolysis-gas chromatography/mass spectrometry to the analysis of lacquer film. Advanced gas chromatography Progress in Agricultural Biomedical and Industrial Applications, Intech, Chroatia, 235-283.

Park, S.Z., 2013, Adhesion characteristics of blended natural glues for the conservation of wooden objects. Master's thesis, Chungbuk National University, Cheongju. (in Korean with English abstract)

Saverwyns, S., Vermeulen, M. and Binnebeke, V.E., 2014, Preliminary investigation of the chemical composition of European lacquers using pyrolysis gas chromatographymass spectrometry. e-PRESERVATION Science, 11, 64-75.

Shedrinsky, A. and Baer, S.N., 2006, Applied pyrolysis handbook. CRC Press Taylor Francis Group, New York, 105-132. Shin, J.H. and Ahan, Y.G., 2013, Identification of the derivated species from traditional coating films. The Korean Society of Community Living Science, 24(2), 243-249. (in Korean with English abstract)

Yang, P.S., 2014, A study on repair and restoration cases of ceramics. Ph. D. dissertation, Kongju National University, Gongju. (in Korean with English abstract) 